\title{
Are you Discussing Dental Caries in Children with Current and Local References? - Letter to The Editor
}

\author{
Martin Hofmeister ${ }^{1}$ \\ ${ }^{1}$ Consumer Centre of the German Federal State of Bavaria, Department of Food and Nutrition, Mozartsraß e 9, D-80336 Munich, \\ Germany.
}

\section{Dear Editor,}

I congratulate the talented team of Dikshit et $\mathrm{al}^{1}$ for their interesting clinical study on the association of body mass index (BMI) with dental caries among Nepalese children, published in a recent issue of the Journal of Nepal Medical Association (JNMA, Mar-Apr, 2018). ${ }^{1}$ There are some aspects worth mentioning.

As a nutrition scientist, I wonder why the authors have highlighted in the discussion section that "... the caries prevalence in children has not shown a significant decline". ${ }^{1}$ This statement is not correct. For example, a comprehensive review conducted by Frencken et al (published in March 2017) found sufficient evidence that the prevalence and severity of cavitated dentine carious lesions among 5- and 12-year-olds has decreased over the last three decades. ${ }^{2}$ Other published data analyses from 2016/2017 have also shown a significant decline in the prevalence and severity of dental caries in children in countries such as Brazil, China, Korea, Thailand, or United States. ${ }^{3-7}$

The authors observed that the prevalence of dental caries of the study participants was $90 \%$. Other investigations with children in Nepal resulted in lower prevalence data (Table 1).

\begin{tabular}{|lllll|}
\hline \multicolumn{4}{|l}{ Table 1. Prevalence of dental caries in Nepalese children by districts. } & \\
\hline District & Age group & $\begin{array}{l}\text { Percent of dental } \\
\text { caries }\end{array}$ & Sample size & Reference \\
Pokhara & $5-7$ years & 20.7 & 3174 & Adhikari et al $(2012)^{8}$ \\
& $8-10$ years & 48.2 & & \\
& $11-14$ years & 52.4 & 361 & Dixit et al $(2013)^{9}$ \\
Chitwan & $5-6$ years & 52.0 & & \\
& $12-13$ years & 41.0 & 616 & Bhagat et al $(2014)^{10}$ \\
Dhankuta and & $5-12$ years & 56.0 & 366 & Shrestha et al $(2014)^{11}$ \\
Sunsari & $12-15$ years & 42.6 & 252 & Khanal et al $(2014)^{12}$ \\
Kathmandu & $12-15$ years & 58.3 & 826 & Thapa et al $(2015)^{13}$ \\
Kathmandu & $5-6$ years & 64.4 & & \\
Nawalparasi & $12-13$ years & 42.2 & & \\
\hline
\end{tabular}

Correspondence: Dr. Martin Hofmeister, Consumer Centre of the German Federal State of Bavaria, Department of Food and Nutrition, Mozartsraß e 9, D-80336 Munich, Germany. Email: hofmeister@ vzbayern.de, Phone: $+49-17661872779$. 
Hofmeister. Are you Discussing Dental Caries in Children with Current and Local References ...

I think in the discussion section the findings should also be compared with existing local literature. For example, in 2016, the relationship of BMI with caries experience (decayed, missing and filled teeth - DMFT) was evaluated at 208 Nepalese children of age three years to six years, who visited the Pediatric Dentistry department of Dhulikhel Hospital, Kavre. Similar to the authors, Upadhyay et al also found no significant association between DMFT and BMI z-scores in the younger studied population. ${ }^{14}$

I fully agree with the authors that there are contradictory results and further local research is needed to examine the relationship between body composition and dental caries among children. The result of a recent meta-analysis of Sun Yat-sen University (Guangzhou, China) is also interesting for this BMI association: Overweight and obese children had significantly more dental caries in their primary as well as permanent teeth in high-income countries, but not in low- and middle-income countries. ${ }^{15}$ Apart from the fact that more confounding factors need to be controlled in addition to standardized measurements in future "oral health" data analyses, the question arises whether other anthropometric parameters such as waist circumference or waist-to-hip ratio are better suited than $\mathrm{BMI}$, in particular for long term associations? ${ }^{16,17}$

Despite the remarkably nutritional achievements of recent years in Nepal, ${ }^{18}$ the authors rightly point out that undernutrition among children is still a major public health problem. In the introduction, a study by Ghosh et al ${ }^{19}$ is cited, which already recorded its high prevalence data in 2007 (44.5\% stunting and 49.3\% underweight). According to the Nepal Demographic and Health Survey, also mentioned by the authors, the prevalence of stunting and underweight among children under five years has fallen in the last 10 years: Stunting $49 \%$ in 2006 to $36 \%$ in 2016, and underweight $39 \%$ in 2006 to $27 \%$ in $2016 .{ }^{20}$ Overall, I think that the good examination by Dikshit et al ${ }^{1}$ can be strengthened by additional discussion.

\section{Conflict of Interest: None.}

\section{REFERENCES}

1. Dikshit P, Limbu S, Bhattarai R. Relationship of body mass index with dental caries among children attending pediatric dental department in an institute. J Nepal Med Assoc. 2018;56(210):582-6. [Full Text]

2. Frencken JE, Sharma P, Stenhouse L, Green D, Laverty D, Dietrich T. Global epidemiology of dental caries and severe periodontitis - a comprehensive review. J Clin Periodontol. 2017;44(Suppl 18):S94-105. [PubMed | DOI]

3. Roncalli AG, Sheiham A, Tsakos G, Araújo-Souza GC, Watt RG. Social factors associated with the decline in caries in Brazilian children between 1996 and 2010. Caries Res. 2016;50(6):551-9. [ubMed | DOI]

4. Zhang X, Yang S, Liao Z, Xu L, Li C, Zeng H, et al. Prevalence and care index of early childhood caries in mainland China: evidence from epidemiological surveys during 1987-2013. Sci Rep. 2016;6:18897. [PubMed | DOI]

5. Kim HN, Han DH, Jun EJ, Kim SY, Jeong SH, Kim JB. The decline in dental caries among Korean children aged 8 and 12 years from 2000 to 2012 focusing SiC Index and DMFT. BMC Oral Health. 2016;16:38. [PubMed | DOI]

6. Srisilapanan P, Nirunsittirat A, Roseman J. Trends over time in dental caries status in urban and rural Thai children. J Clin Exp Dent. 2017;9(10):e1201-6. [PubMed | DOI]

7. Dye BA, Mitnik GL, Iafolla TJ, Vargas CM. Trends in dental caries in children and adolescents according to poverty status in the United States from 1999 through 2004 and from 2011 through 2014. J Am Dent Assoc. 2017;148(8):550-65. [PubMed | DOI]

8. Adhikari RB, Malla N, Bhandari PS. Prevalence and treatment needs of dental caries in school-going children attending dental outpatient department of a tertiary care centre in western region of Nepal. J Nep Med Sci. 2012;1(2):115-8. [Full $\underline{\text { Text }}$ | DOI]

9. Dixit LP, Shakya A, Shrestha M, Shrestha A. Dental caries prevalence, oral health knowledge and practice among indigenous Chepang school children of Nepal. BMC Oral Health. 2013;13:20. [PubMed | Full Text]

10. Bhagat TK, Shrestha A. Dental caries experience among school children of Eastern Nepal - significant caries index. Health Renaissance. 2014;12(2):74-7. [Full Text | DOI]

11. Shrestha N, Acharya J, Sagtani AR, Shrestha R, Shrestha S. Occurrence of dental caries in primary and permanent dentition, oral health status and treatment needs among 12-15 year old school children of Jorpati VDC, Kathmandu. Nepal Med Coll J. 2014;16(2-4):109-14. [ $\underline{\text { PubMed | Full Text] }}$

12. Khanal S, Acharya J. Dental caries status and oral health practice among 12-15 year old children in Jorpati, Kathmandu. Nepal Med Coll J. 2014;16(1):84-7. [PubMed | Full Text]

13. Thapa P, Aryal KK, Dhimal M, Mehata S, Pokhrel AU, Pandit A, et al. Oral health condition of school children in Nawalparasi district, Nepal. J Nepal Health Res Counc. 2015;13(29):7-13. [PubMed | Full Text]

14. Upadhyay S, Srii R, Srivastava S, Karki S. Relationship of early childhood caries and body mass index in children attending a tertiary health care center of Nepal. International Journal of Scientific Research. 2016;5(12):12-4. [Full Text]

15. Chen D, Zhi Q, Zhou Y, Tao Y, Wu L, Lin H. Association between dental caries and BMI in children: a systematic review and meta-analysis. Caries Res. 2018;52(3):230-45. [ubMed | DOI] 
16. Peng SM, Wong HM, King NM, McGrath C. Association between dental caries and adiposity status (general, central, and peripheral adiposity) in 12-year-old children. Caries Res. 2014;48(1):32-8. [PubMed | Full Text]

17. Li LW, Wong HM, McGrath CP. Longitudinal association between obesity and dental caries in adolescents. J Pediatr. 2017;189:149-54. [PubMed | DOI]

18. Cunningham K, Headey D, Singh A, Karmacharya C, Rana
PP. Maternal and child nutrition in Nepal: examining drivers of progress from the mid-1990s to 2010s. Glob Food Sec. 2017;13, 30-7. [Full Text | DOI]

19. Ghosh A, Adhikari P, Chowdhury SD, Ghosh T. Prevalence of undernutrition in Nepalese children. Ann Hum Biol. 2009;36(1):38-45. [uued | Full Text | DOI ]

20. Ministry of Health, Nepal; New ERA; and ICF. Nepal Demographic and Health Survey 2016. Kathmandu, Nepal: Ministry of Health, Nepal. 2017. [Full Text]

This work is licensed under a Creative Commons Attribution 4.0 International License. The images or other third party material in this article are included in the article's Creative Commons license, unless indicated otherwise in the credit line; if the material is not included under the Creative Commons license, users will need to obtain permission from the license holder to reproduce the material. To view a copy of this license, visit http://creativecommons.org/licenses/by/4.0/ 